\title{
Balkan Conflict, the Disintegration of Yugoslavia and the ICTY
}

\author{
Veton Zejnullahi \\ Universiteti i tiranës \\ Instituti I Studimeve Evropiane \\ vetonz@hotmail.com
}

DOI:10.5901/mjss.2014.v5n19p264

\begin{abstract}
Yugoslavia as South Slavic state, initially formed in 1918, under the name of Kingdom of three Slavic peoples: Slovenes, Croats and Serbs, and then as communist country, established after the World War II, has played an important role in regional and international politics. The new federation consisted of six republics and two autonomous provinces, which were constitutive elements of federation having the right of veto. Yugoslav state played an important role on the international stage, especially through Non-Aligned Movement which was founded with India and Egypt. Its leader, Josip Broz Tito, has suppressed nationalism in all the republics and thus managed to keep the Yugoslav nations united around the communist idea, by transforming Yugoslavia into a very strong economic and military country. But, after his death in 1980, nationalisms surfaced and began disintegrating the federation. In this regard, the Serbian nationalism has been particularly distinguished, which has by the use of the Yugoslav National Army (JNA) started wars against other peoples of the Yugoslav federation, who sought secession and independence of their republics. Initially the war started against Slovenia, then Croatia, Bosnia and Herzegovina and more recently against Kosovo Albanians. After many bloody wars that left hundreds of thousands of casualties and millions of refugees, two international conferences had to be held, one in Dayton for Bosnia and Herzegovina and in Rambouillet for Kosovo, including 78-day intervention of NATO aviation aimed to put an end to the never ending conflicts. The resolution of the UN Security Council has also established the Tribunal of Hague which would investigate and adjudicate the crimes committed in Yugoslavia. This Tribunal has imposed 1000 years in prison, especially for Serb military and political leaders. The breakup of the former Yugoslavia resulted in formation of seven new states which are in the path of Euro-Atlantic integration as Slovenia and Croatia which are already permanent members of these organizations.
\end{abstract}

Keywords: Former Yugoslavia, nationalism, conflict, ICTY, international community

\section{The purpose of the paper}

The purpose of this resarch paper is to exsplain how it came to be the disintegration of communist Yugoslavia, as well as the causes and consequences. In the paper clearly shows the impact of the Yugoslav state in the international arena, in economic and especially in the politik terms. Yugoslavia was an federation of different nations with different cultures and with three major religions who for half a century lived together in harmony, inspired by the communist idea of state and party leadership of the country

We will also see that after the end of the Cold War and the revival of nationalism, Yugoslavia became involved in the wars which were followed by the most atrocious crimes and scenes which were seen only during World War II. The bombing of the ancient city of Dubrovnik, flattening as a land of Vukovar city in Croatia, the siege of Sarajevo, the massacre in Srebrenica in Bosnia and Herzegovina and deportation with the trains of Kosovo Albanians are the best evidence of what happened in Yugoslavia. We will see that the war had hundreds of thousands killed, raped, with millions of refugees and destroyed of economy which is still weak and still require time. We remind that in the territory of Yugoslavia occurred six diffferent wars. For every think that happened the International community's as the main guilty main fault declared Federal Republic of Yugoslavia.

\section{Analysis of of the conflict in former Yugoslavia}

With the collapse of communism and the reappearance of nationalism in Eastern Europe during the 80s and early 90s, Yugoslavia experienced a period of heavy political crisis and economic. The central government was weakened while 
militant nationalism strengthened. In scene came many political parties, some of which are committed to the immediate independence of the republics and others seeking greater powers for some specific republic within the federation.

Political leaders began using nationalist rhetoric to eradicate common Yugoslav identity and fostering fear and distrust among the different ethnic groups. In 1991 breakup of Yugoslavia was approaching at a time when Slovenia and Croatia blamed Serbia for unfair dominance of the Yugoslav government, army and finances. Serbia on the other side of accusing these two republics to the Balkans separatism. Balkan problematic history starting from dates of nationalistic doctrines of statehood. These doctrines were not fully unfolded as simultaneously and fully national identity platforms with the political goals. (Lisen Bashkurti, On international law and International organisation, Gerr, Tiranë, 2006, f.103)

The main causes of dissolution of the Yugoslav federation dealing with the deep economic crisis, the big interethnic hate of its peoples, nationalism and international circumstances. An important fact is the role of leaders ranging from Josip Broz Tito to the last leaders who definitely destroyed Yugoslavia.

The rebirth of the nationalism for big Serbia, must have a cause, which can be linked to the collapse of the Yugoslav economy. (William Blum, The CIA and the U.S. military, Tirana, 2005, p. 585)

Serbia sped up the dissolution process of the Yugoslav Federation, being prepared for conflicts that would bring terrible wars in the regions of Yugoslavia. (Ana Lalaj, Kosovo, The long path towards self-determination 1948-1981, Tirana, 2000, p. 48)

Action that laid the peak of Yugoslav crisis, was the joint maintaining of the JNA, the Yugoslav army, driven by Serbian hegemonism, led by Slobodan Milosevic, mainly for the Serbian interests. But, in front of the world and in front of other peoples of Yugoslavia was insisted on preserving the territorial integrity of AVNOJ Yugoslavia. Here initially started undoing of the only common thread that was left of the Yugoslav community - its army. (Ramë Buja, Conference of Rambujese, Prishtinë, 2006, f. 27 - 29)

Slovenia's declaration of independence actually ended the existence of the SFRY. After the declaration of independence of Croatia, Macedonia, and Bosnia and Herzegovina at April 1992, the federation were left only with Serbia and Montenegro. The remaining two republics declared the Federal Republic of Yugoslavia (FRY) at 27 April 1992. In 2003, the Federal Republic of Yugoslavia was reconstituted and changed its name to the State Union of Serbia and Montenegro. This union was disbanded by proclamation of independence of Montenegro on 3 June 2006 and Serbia on 5 June 2006. U.S. funding have access to all social environments of the federation, which had begun the democratic party or movement. (William Blum, The CIA and the U.S. military, Tirana, 2005, 587)

As a result of direct involvement in all wars that were taking place, the Federal Republic of Yugoslavia was strongly condemned by the international community for its role in these wars and it was decided to stricter economic sanctions, military, cultural and sporting. So a lot of success occurred when issuing the resolution for so called Yugoslavia, when was decided to remove her from all international institutions, deciding an embargo, UN forces were sent in the territories where the fight took place and for penalty of Serbia and Montenegro, although as a aggressors, but in this regard had major delays. (Karen A. Mingst, Bazat e marrëdhënieve ndërkombëtare, Tiranë, 2008, f. 222), Fundamentals of international relations, Tirana, 2008, p. 222)

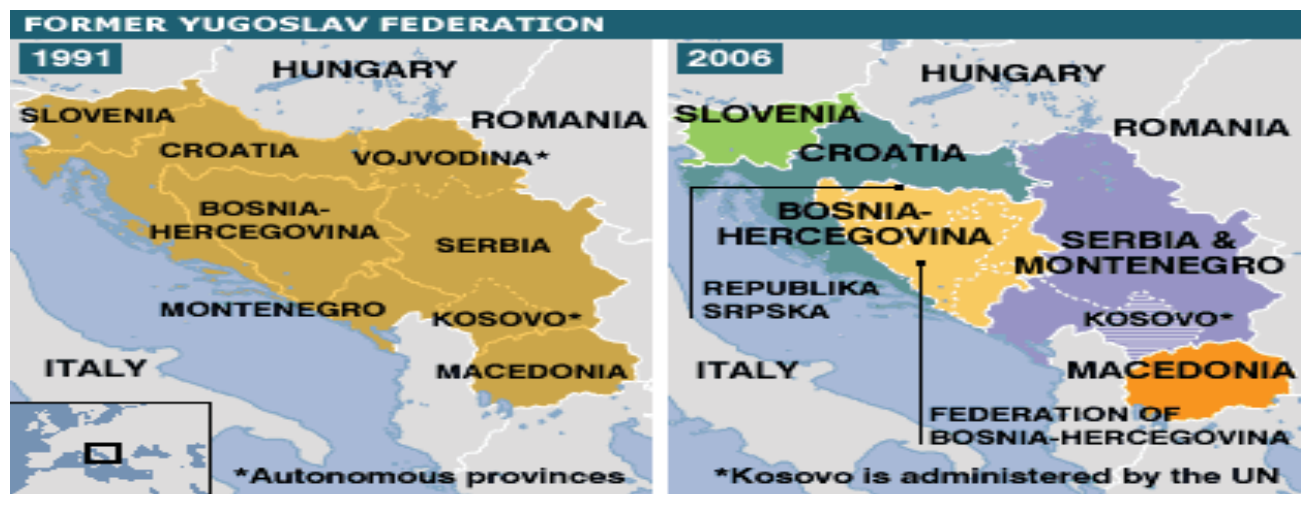


Map of former Jugosllavisë before and after the war (http://newsimg.bbc.co.uk),

Chronology of the dissolution of former Yugoslavia

The process of dissolution began with the coming to the power of Slobodan Milosevic in Serbia and the drafting of the Memorandum of the Academy of Sciences and Arts of Serbia, under which Serbia was not equal to other republics in the former Yogosllavia federation because the Kosovo and Vojvodina as a two autonomous provinces had elements of the Serbian statehood.Serbian regime began with aggressive policy towards the two provinces until termination of their autonomy in March of 1989, that was followed by Kosovo Albanian protests that were crushed by violence, many citizens were killed.Disclosure of Serbian program for a big Serbia by threatening other nations with war occurred in June 1989 near Pristina in Gazimestan marking the defeat of the Serbs by the Ottomans 600 years ago. This threat came directly from Serbian President Slobodan Milosevic. Later it will be understood that the plan was that the Serbs within Serbia to enter Bosnia and Herzegovina, Montenegro and part of Croatia at the points of Karlovac-Karlobag-Virovitica.

The republics in the west of the country Slovenia and Croatia seeing these actions of Serbia initially reacted in the 14th Congress CCY, by leaving the hall in protest and dissent against Serbian domination tendencies by giving clear signs that they think of separation from Yugoslavia. Exactly the 14th Congress of CCY held in January of 1990 marks the end of what was called Yugoslavia. In the meantime, all the republics and provinces were formed political parties that engage in Jugosllavia.The 1991 marks the beginning of the end of Yugoslavia because in June 1991 Sllovenia marks declaration of independence, she was the first that was seperated formally from Yugoslavia.

This attack caused the Yugoslav National Army (JNA) which resulted in a short military conflict, known as the "ten days War" which ended with the victory of the Slovenian forces and the withdrawal of forces and armament of the JNA. There is a general conviction that Yugoslavia especially Serbia itself was specifically interested in the removal of Slovenia from the federation because in this way would have a less enemy towards in the realization of the project for the creation of a Big Serbia.

Yugoslav army was deployed in Croatia where the local Serbs expected uprising against the Croatian government, in the meantime Croatian government was changed and was leded by Croatian nationalists who tried as the same as those Slovenians.Croatia declared independence on the same date with Slovenia, but oppositely from Sllovenia in Croatia the local Serb uprising with the help of the JNA and Serbia and declared their independent state in nearly a third of Croatian territory which was called Serbian Republic of Krajinës while Croats and non-Serbs nations were deported from the area in a violent campaign of ethnic cleansing. Fierce fighting during the second half of 1991 included the bombing of the ancient city of Dubrovnik and Vukovar siege and destruction of Serb forces.

But in the summer of 1995, the Croatian Army launched two major offensives codenamed "Storm" and took control of the entire territory except a corner known as Eastern Slavonia which was integrated in Croatia in January 1998 during a peaceful transition under United Nations administration.

The struggle was happened also in Bosnjë and Herzegovina and the savagery was the bloodiest of all conflicts of dissolution of Yugosllavia. The strategic position of this republic made him the object of effort and Croatian Serb-dominated part of its territory. In fact, the leaders of Serbia and Croatia had met secretly in 1991 in Karadjordjevo and had agreed on the division of Bosnia and Herzegovina and to leave the muslims a small enclave .

In March of 1992, in referendum which Serb boycotted, more than $60 \%$ of citizens of Bosnja and Hercegovina voted for independence. Almost immediately thereafter, in April 1992, Serbians from Bosnja rebelled with support of the JNA and Serbia and declared Serbian Republic of Bosnia and Herzegovina in the territories controlled by them.

It is estimated that over 200,000 people were killed, thousands of Bosnian women were systematically raped and two million people, or more than half the population, were forced to leave their homes as a result of the war that lasted from April 1992 to November 1995 when the peace agreement was signed in Dayton.

Rudolf Perina, head of diplomatic missions in Belgrade, participant of Bosnia Peace Conference was direct, in a statement:' In Dayton were invited people those who fight."(Blerim Shala: Vitet e Kosovës 1998 - 1999, Prishtinë, 2001, f. 22). All parties to the conflict created the infamous concentration camps for civilians in Prijedor, Omarska, Konjic, Dretel, and other countries.

The biggest crime carried out during this war happened in the summer of 1995, when the Bosnian town of Srebrenica, which was declared a protected area by the United Nations, was attacked by forces led by Bosnian Serb commander Ratko Mladic. Within a few days in early July, over 8,000 mens and boys Bosnian Muslims were executed by Serb forces in an act of genocide. The remaining women and children were expelled from the city. It is interesting to note that prior to the 
execution of Bosniaks in Srebrenica a Serbian Orthodox priest blessed the arms of those who will carry out the massacre. The choice was made for Bosnia and Herzegovina is not a good example of solving international crises.

At the end of Dayton summit, the U.S. government came to a stay in a document that was a resume of the U.S. Department of State Summit, which became known that the outer wall of sanctions against Serbia remain in force, unless other constraints, was the solution of the Kosovo issue, which means that this attitude of the U.S. administration for Kosovo was clear, but Summit didnt brought anything single and unique for that. (Ramë Buja: konferenca e Rambujesë, Prishtinë, 2006, f.43)

According to Richard Holbrooke:" Dayton conference had a very busy and complex agenda, so that when it enters the Kosovo issue would endanger the negotiation process and the peace agreement may not be reached ". (Greg Capmbell: The Road to Kosovo, A Balkan Diary, Colorado, London, 2000, p. 153)

But Kosovo it was exactly the other areas of conflict, where the Albanian majority demanded independence by continuing with the method of civil resistance that was started in 1990. In 1998, violence erupted becauce the Kosovo Liberation Army (KLA), enjoyed the support of a majority Kosovar Albanians was set up in open revolt against Serbian rule, which resulted in the deployment of military and police forces to suppress the insurgents. In their campaign, Serb forces attacked civilians being shelled villages and forcing Kosovo Albanians to leave their homes. This situation coincides exactly with the words Vasa Çubriloviq Serbian academician since 1937 when he says that "It remains to be used a method which Serbia has practically used after 1878, burned secretly villages and parts of the city where Albanians live." (Srbija i Albanci, knjiga prva,Ljubljana, 1989)

So Serbia had not waived continuing Kosovo war and using the same actions: violence, massacres, deportations, burning" But even this form of Serbian terror war to disrupt the momentum of the Albanian and the Kosovo Liberation Army ." (Misha Glenny, The Fall of Yougosllavia, London, 1996, p. 33)

After the failure of efforts to resolve the crisis in talks mediated by the international community in Rambouillet, NATO conducted a 78-day campaign of air attacks against targets in Kosovo and Serbia.

In response, Serbian forces intensified persecution of Kosovo Albanian civilians being deported over a million Albanians from Kosovo. Form of deportation trains to Macedonia was completely the same with what the German Nazis did to the Jewish people during World War II. In the end, Serbian President Slobodan Milosevic agreed to withdraw military forces and police from Kosovo. About a million Albanian refugees returned to their homes and about 100,000 Serbs fled Kosovo for fear of retaliation. In June 1999, Serbia accepted international administration of Kosovo before determining its final status, which was determined on 17 February 2008 when Kosovo's parliament declared independence which is currently recognized by 106 countries of the world and which was confirmed International Court of Justice.

After the loss suffered in the Kosovo war and leaving forever from Kosovo in 1999, the majority of Serbian forces were deployed in the Presevo Valley to become even more difficult situation already quite irritated and turning it into a new area of conflict, should know that municipalities Presevo is mostly Albanians in Serbia. (http://www.kt.gov.rs/t/articles/presheva/)

This situation became unbearable and the population began to organize itself by forming self-defense UÇPMB is the abbreviation for the Liberation Army of Presevo, Medvegja and Bujanovac where conflict broke Serbian government forces. The intervention of the international community was immediate and after much consultation with the Albanian as well as Serbian special envoy of the Secretary General of NATO Ambassador Pieter Feith managed to reduce the negotiating table Serbian and Albanian sides.

In these talks Peace Agreement was reached with the name "Konçul Agreement" but the situation remains the same, with the only difference that the population massively outgoing towards Kosovo and Western European countries, especially after the removal of visa regime by the EU Serbia.Besides the conflict in the Presevo Valley war broke out in Macedonia, which was on the southern republics of the Yugoslav federation, and which declared independence in the fall of 1991 and had a peaceful separation. Later was admitted to the United Nations with a temporary name - Former Yugoslav Republic of Macedonia (FYROM).

Former Yugoslav Republic of Macedonia, whose population consists of Macedonians and Albanians and some minorities, peace experienced during Yugoslav fighters during the 90s. Being defined as a state only Macedonians and Albanians induced response in early January 2001, the National Liberation Army (NLA) of ethnic Albanians confronted with security forces seeking autonomy or independence for areas inhabited by Albanians in this country. Armed conflict was held for several months in 2001 and ended with a peace agreement - "The agreement of the Ohrid Framework" which provided for power sharing, disarmament of Albanian fighters, and deployment of a force of NATO supervision. But even though it has 
been over 10 years since the war such agreement has not yet been fully implemented due to the numerous obstacles that come from the Skopje government

\section{The Tribunal of Hague- ICTY}

Numerous atrocities carried out in Croatia initially and later in Bosnia and Herzegovina urged the international community to act. Since 1991, the United Nations took note of the situation and then encouraged parties in the conflict to respect international law. Reports of the massacre of thousands of civilians, rape and torture in prison camp, horrible images from surrounded cities and the suffering of hundreds of thousands displaced people from their homes set increased the awarness to move and take the step of the United Nations for the establishment of the commission of experts to assess the situation on the ground at the end of 1992.

In its report, the commission documented the terrible crimes and gave the UN Security General Secretary's evidence of serious violations of the Geneva Conventions and other violations of international humanitarian law. Based on these facts on May 25, 1993, the UN Security Council adopted Resolution 827. (http://www.un.org/en/sc/repertoire/9699/Chapter\%208/Europe/96_99_8_European_27D_International\%20Criminal\%20T ribunal.pdf)

Thus establishing the International Criminal Tribunal for the former Yugoslavia, known as the ICTY. This resolution contained ICTY Statute which determined the jurisdiction and the organizational structure as well as general criminal tribunal procedures. It was the first war crimes court's established by the United Nations and the first tribunal for war crimes since Nurenbergut and Tokyo tribunals. This date marked the beginning of the end of impunity for war crimes in the former Yugoslavia.

\section{The achievements of the Tribunal -Bringing the leaders in front of responsibilities}

By putting individuals in front of the responsibilites despite of their position, the tribunal has broken the tradition of impunity of war crimes. Tribunal raised charges against heads of state, prime ministers, army chiefs, members of governments and many other leaders from various parties in the conflict in Yugoslavia. Thanks tribunal, no question arises on whether leaders must be held accountable, but how we can be held accountable. " European barbarism showed itself in the Balkans, with a neighbor, and neighbor killed in fratricidal wars that cost more than 200,000 lives and for ethnic cleansing of millions of human beings, mostly Muslims of Bosnia and Kosovo." (Garton Ash Anthony, the Free World, Random House, New York, 2004, p. 52)

\section{Conclusions and recommendations}

From all what was mention in this paper rightly conclude that the former Yugoslavia had a significant role in regional and the international politics. International circumstances, especially the Cold War between the two blocs, East and West that enabled a very active role, especially through movement of not involvement in which way was introduced between these blocks.. Even though it was a country that unite different peoples with different cultures and with three major religions, these people lived for half a century in harmony with each other under the leadership of Yugoslav communists. Also note that the nationalisms of all oppressed peoples and boundless faith was for national army of Jugosllavia. But with the fall of the Berlin Wall as a symbol of communism and the division into blocks also Yugoslavia nationalist formed political parties and began to think of dividing from federation. More aggressive in this regard was shown Serbian nationalism which was the cause of many wars to claim the creation of a Big Serbia. The main reasons for the dissolution of Yugoslavia as was mentioned were economic situation, nationalism, international circumstances and the role of leaders.During process of disintegration of Yugoslavia was held six different scale conflicts that left over 300,000 people killed, thousands of women raped on mainly Bosnian Muslim, 2-3 million were refugees and was causing the war which world had not experienced since World War II. Dubrovnik, Vukovar, Srebrenica, Racak deportation trains Kosovo Albanians were the reasons that the international community Tribunal initially formed recently and used the force (Kosovo case) to stop the crimes.

Also we can conclude that the Tribunal imposed over 1,000 years in prison for the accused who were mostly Serb political and military leadership and innovation was putting in front of responsibilities of the political leaders (heads of states, prime ministers, ministers) or military (General, Admiral or the lower ranks), therefore no longer admitted dilemma whether to put 
in front of responsibiliites but the dilemma was how to put in front some of them are which were hidden for years from the international justice.

In the end we can conclude that the dissolution of Yugoslavia was the bloodiest war compering of the dissolution of other Eastern Bloc countries such a countries from former USSR Czechoslovakia becauce during the breakup of Yugoslavia because the horrors of war have experienced all of its people . whereas nowadays all seven countries formed from the former Yugoslavia have as main objective the Euro-Atlantic integrations, while two of them now Slovenia and Croatia are members of these organizations, while other countries are underway.

\section{Literature}

1.Lisen Bashkurti, Mbi të drejtën ndërkombëtare dhe organizatat ndërkombëtare, Gerr, Tiranë, 2006, f.103

2.Ana Lalaj, Kosova, rruga e gjatë drejt vetëvendosjes 1948 - 1981, Tiranë, 2000, f. 48

3.Ramë Buja, Konferenca e Rambujesë, Prishtinë, 2006, f. 27 - 29 dhe 43

4.William Blum, CIA dhe ushtria amerikane, Tiranë, 2005, fq.585, 587

5.Karen A. Mingst, Bazat e marrëdhënieve ndërkombëtare, Tiranë, 2008, f. 222

6.http://newsimg.bbc.co.uk

7.Blerim Shala: Vitet e Kosovës 1998 - 1999, Prishtinë, 2001, f. 22

8.Greg Capmbell: The Road to Kosovo, A Balkan Diary, Colorado, London, 2000, f. 153

9.Srbija i Albanci, knjiga prva,Ljubljana, 1989

10.Misha Glenny, The Fall of Yougosllavia, London, 1996, f. 33

11.http://www.kt.gov.rs/lt/articles/presheval

12.http://www.un.org/en/sc/repertoire/9699/Chapter\%208/Europe/96_99_8_European_27D_

International\%20Criminal\%20Tribunal.pdf

13.Ash Garton Anthony, Fre World, Random House, New York, 2004, f. 52

14.Eva Tafili ( Hyskaj), Sfidat e nacionalizmit rasti i Ballkanit

15.Shaban Murati, Profile të diplomacisë europiane në Ballkan,Tiranë 2009

16.Nedokucivi Balkan, Hesperia 2009, Beograd 